\title{
Mide ve kolon kanserlerinde metastaz göstergesi olarak serum folat ve vitamin B12 düzeylerinin irdelenmesi
}

\author{
The evaluation of serum folate and B12 levels as markers of liver metastases in stomach and colon
} cancer

Veli ÇAKICI ${ }^{1}$, Elif YORULMAZ2 , Hasan Hüseyin MUTLU ${ }^{1}$, Celal ULAŞOĞLU², Mehmet ÇELIK ${ }^{1}$, Ilyas TUNCER ${ }^{2}$, Hilmi ÇIFTCI ${ }^{1}$, Gözde DERVIŞ HAKIM ${ }^{1}$, Hacer Hicran BEYCA³ ${ }^{3}$ Ebubekir ŞENATEŞ²

Istanbul Medeniyet Üniversitesi Göztepe Eğitim ve Araştırma Hastanesi ${ }^{1}{ }^{1} c ̧$ Hastalıları Kliniğ̈i, ${ }^{2}$ Gastroenteroloji Kliniği, Istanbul Bezmialem Vakıf Üniversitesi Tip Fakültesi ${ }^{3}$ Onkoloji Kliniği, Istanbul

Giriş ve Amaç: Vitamin B12 ve folat hücre bölünmesi ve çoğalması için gerekli olan DNA yapımında yer alan iki önemli vitamindir. Bu çalışmada vitamin $B 12$ ve folat düzeylerinin mide ve kolon kanserinde karaciğer metastazı göstergesi olarak değerlendirilmesi amaçlandı. Gereç ve Yöntem: Çalısmaya 30 mide kanserli ve 30 kolon kanserli hasta ile kontrol grubu olarak 30 sağhklı kişi alındı. Hastaların karaciğer metastazları bilgisayarlı tomografi ile değerlendirildi. Metastatik olan ve olmayan gruplar vitamin B12 ve folat düzeyleri açısından karşılaştırıldı. Bulgular: Mide kanserli hastalarnn 12 'sinde (\%40), kolon kanserli hastalarnn 8'inde (\%25.8) karaciğer metastazı saptandi. Folat değerleri, kanserli grupta kontrol grubuna göre anlamlı derecede düşük bulunurken ( $p<0.01$ ), B12 düzeyi ise anlamlı derecede yüksek saptand $(p<0.05)$. Kolon kanserli hastalarda karaciğer metastazı olan grupta B12 düzeyi, metastaz olmayan gruba göre anlamlı derecede yüksek saptand (p<0.05). Sonuç: Kolon kanserinde B12 düzeyinin belirgin yüksekliği karaciğer metastazını gösteren bir parametre olabilir. Folik asid her iki kanser grubunda kontrol grubuna göre anlamlı düşük düzeyde bulundu. Folat replasmanının bu kanser grubunun profilaksisinde etkinliği ve B12 yüksekliğinin metastaz mevcudiyeti ile ilişkisini aydınlatmak için geniş ölçekli çalışmalara ihtiyaç olduğu sonucuna varıldı.

Anahtar kelimeler: Folat, kolon kanseri, mide kanseri, vitamin B12

\section{GİRIS}

Vitamin B12 ve folat hücre bölünmesi ve DNA replikasyonu için gerekli olan iki önemli vitamindir. Folat tek karbonlu yapıların değişik organik bileşiklere taşınması için gereklidir. Metiyonin sentezi, timidilat sentezi, glisin sentezi, pürin sentezi ve histidin katabolizması gibi önemli tepkimelerde görev alır (1). Homosistein metionin dönüşümünü sağlayan metionin sentetaz kofaktör olarak vitamin B12 kullanır. Folat bu reaksiyona tek karbonlu yapıların katılmasını sağlar. Metionin daha sonra DNA ve diğer moleküllerin metilasyonundan sorumlu S-adenozil metionin (S-AM)'e dönüşür. DNA'nın metilasyonu, genomun stabilize olmasına ve gen expresyonunun regülasyonuna katkıda bulunur (2). DNA sentezinde hız sınırlayıcı basamağı katalizleyen timidilat sentetaz, kofaktör olarak folatı kullanır. Bu nedenle DNA sentez, tamir ve metilasyonunda önemli olan folatın düşük seviyesinin bazı kanserlerle ilişkisi olması beklenebilir. Diyette yetersiz folat alımı; serviks $\mathrm{Ca}$, akciğer Ca ve meme Ca gibi birçok epitelyal kanser gelişimine neden olur. Epidemiyolojik çalışmaların büyük kıs-
Background and Aims: Vitamin B12 and folate are two important vitamins necessary for cell division, proliferation and DNA synthesis. In this study, we aimed to evaluate the levels of B12 and folate as indicators of liver metastases of stomach and colon cancer. Materials and Methods: The study group consisted of 31 patients with colon cancer, 30 patients with gastric cancer and 30 healthy control subjects. Presence of liver metastases was evaluated by computerized tomography. Patients with or without liver metastases were compared with the control group in terms of vitamin B12 and folate levels. Results: Twelve (40\%) patients with gastric cancer and 8 (25.8\%) patients with colon cancer had liver metastases. Folate levels were significantly lower $(p<0.01)$ while vitamin B12 levels were significantly higher $(p<0.05)$ in cancer patients compared to the control group. Mean B12 level was higher in metastatic colon cancer cases than in those without metastases $(p<0.05)$. Conclusions: Vitamin $B 12$ levels were significantly higher in metastatic stomach and colon cancer cases compared to non-metastatic cases. Cancer cases had lower levels of folate compared to healthy controls, but levels were similar between metastatic and non-metastatic cases. It is concluded that large-scale studies are necessary to elucidate the relationship between the presence of metastasis and B12 levels, especially in cases with colon cancer.

Keywords: Folate, colon cancer, gastric cancer, vitamin B12

mında folat alımı (KRK) riskiyle ters orantılı bulunmuştur (3). Serum vitamin B12 düzeylerindeki yükselme, hayatı tehdit eden ciddi hastalıkların işareti olabilir. Kronik myeloid lösemi, premyelositik lösemi, polistemia vera ve hipereozinofilik sendrom gibi hematolojik hastalıklarda vitamin B12 düzeyi yüksektir. Dolaşımdaki vitamin B12 düzeyi yükselmesine öncelikle hepatik hücrelerde vitamin B12'nin bağlayıcısı haptocorrin üretimi sebep olur. Akut hepatit, siroz, hepatosellüler kanser (HSK) ve metastatik karaciğer hastalıkları gibi birçok karaciğer hastalığı, dolaşımdaki vitamin B12 yüksekliğine sebep olur. Bu yükseklik özellikle karaciğer hücre sitolizindeki artmış salınımına veya hepatosit etkilenmesine bağlı vitamin B12 klerensinin düşmesine bağlıdır $(4,5)$. Bu çalışmada günlük pratikte serum folat ve vitamin B12 düzeyinin mide ve kolon kanseri tanısı koymadaki önemi ve karaciğere metastaz yaptığı belirlenmiş olgulardaki düzeylerinin karaciğer metastazını göstermedeki etkinliğinin tespit edilmesi amaçlanmıştır. 
Tablo 1. Mide ve kolon kanseri gruplarının folat ve vitamin B12 düzeylerinin karşılaştırılması

\begin{tabular}{lcccc} 
& Mide kanseri & Kolon kanseri & Kontrol grup & $p$ \\
Folat & $7,26 \pm 3,98$ & $7,57 \pm 3,88$ & $9,77 \pm 3,42$ & 0,004 \\
Vit B12 & $631 \pm 535,86$ & $570,6 \pm 549,8$ & $291,24 \pm 112,78$ & \\
\hline
\end{tabular}

\begin{tabular}{llccc} 
Tablo 2. Metastatik mide ve kolon kanseri gruplarının folat ve Vitamin B12 düzeylerinin karşılaştırılması & \multicolumn{1}{c}{ Metastaz (+) } & p \\
Mide kanseri & Folat & Metastaz (-) & $6,37 \pm 3,98$ & 0,197 \\
& Vit B12 & $7,86 \pm 3,97$ & $814,21 \pm 642,18$ & 0,108 \\
Kolon kanseri & Folat & $508,86 \pm 428,36$ & $6,67 \pm 4,01$ & 0,206 \\
& Vit B12 & $7,89 \pm 3,87$ & $954,94 \pm 725$ & 0,034
\end{tabular}

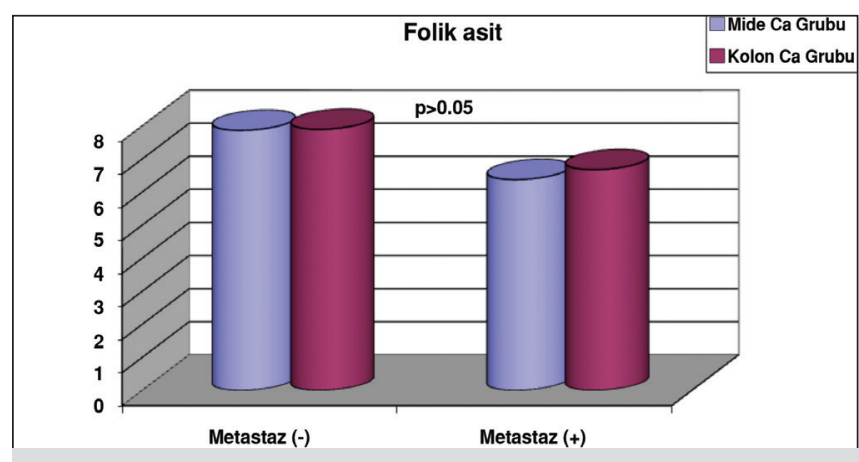

Şekil 1. Metastatik mide ve kolon kanseri gruplarının folat ortalamaları

\section{GEREÇ ve YÖNTEM}

Hasta Popülasyonu

Çalışmaya yeni tanı konulmuş 30 mide kanserli (20 erkek, 10 kadın), 31 kolon kanserli (16 erkek, 15 kadın) hasta ve 30 sağlıklı birey (16 erkek, 14 kadın) alındı. Hastaların sigara ve alkol alışkanlıkları, bilinen kronik hastalık öyküsü, ailede malignite varlığı, kullandıkları ilaçlar sorgulandı ve kaydedildi. Daha önceden vitamin preperatı kullananlar, başka bilinen hastalık ve operasyon öyküsü olanlar çalışma dışı bırakıldı. Hastaların yapılan endoskopik, biyokimyasal, radyolojik ve patolojik sonuçları incelenip, karaciğer metastazı yapmış ve yapmamış olguların sonuçları değerlendirildi. Hastaların karaciğer metastazları komputerize tomografi incelenmesinde değerlendirilerek, vitamin B12 ve folat düzeyleri ile karşılaştırıldı. Çalışma için hastane yerel etik kurul onayı alındı ve hastalar çalışma ile ilgili bilgilendirildi (02/06/2009, No:57).

\section{Laboratuvar Yöntemi}

Vitamin B12 ve folat düzeyleri hastanemiz biyokimya laboratuvarında, Roche marka E170 ECL model cihazla, kemilüminesans yöntemiyle serumda ölçüldü. Sonuçlar sayısal değer olarak verildi.

\section{İstatistiksel Analiz}

Bu çalışmada istatistiksel analizler, NCSS 2007 paket prog-

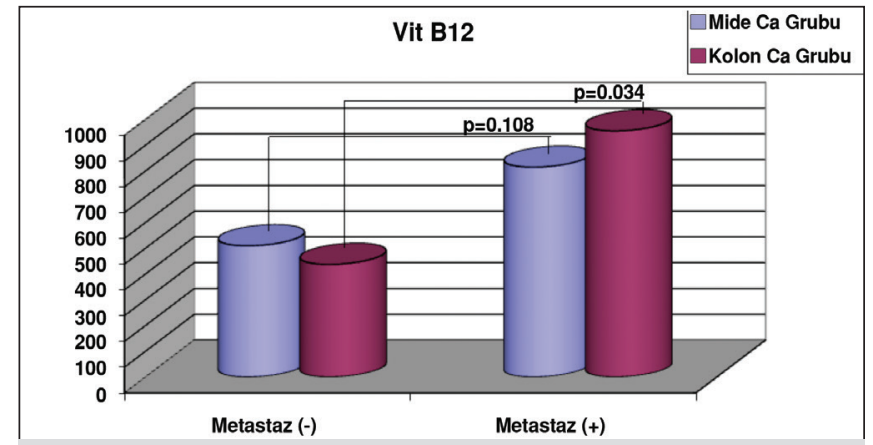

Şekil 2. Metastatik mide ve kolon kanseri gruplarının vitamin B12 ortalamaları

ramı ile yapılmıştır. Verilerin değerlendirilmesinde, tanımlayıcı istatistiksel metotların (ortalama, standart sapma) yanı sıra gruplar arası karşılaştırmalarda Kruskal Wallis testi, alt grup karşılaştırmalarında Dunn's çoklu karşılaştırma testi, ikili grupların karşılaştırmasında Mann-Whitney-U testi, nitel verilerin karşılaştırmalarında ki-kare testi kullanılmıştır. Sonuçlar, anlamlılık p<0,05 düzeyinde değerlendirilmiştir.

\section{BULGULAR}

Çalışmaya 31 kolon kanserli 16 erkek, 15 kadın (ortalama yaş

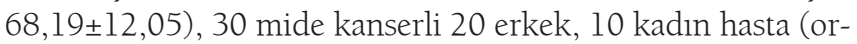
talama yaş $65,13 \pm 13,39$ ) ve 16 erkek, 14 kadın (ortalama yaş $65,36 \pm 11,79) 30$ sağlıklı kontrol grubu alındı. Folat değerleri kanserli grupta kontrol grubuna göre anlamlı derecede düşük ( $<<0.01)$, vitamin B12 düzeyi ise anlamlı derecede yüksek saptand $(\mathrm{p}<0.05)$ (Tablo 1). Mide kanserli hastaların 12'sinde (\%40), kolon kanserli hastaların 8'inde (\%25.8) karaciğer metastazı saptandı. Mide kanserli hastalarda karaciğer metastazı olan grupta vitamin B12 düzeyi karaciğer metastazı olmayan gruba göre daha yüksek olmasına karşın anlamlı ilişki saptanmadı ( $>0.05)$. Kolon kanserli hastalarda karaciğer metastazl olan grupta vitamin B12 düzeyi, metastaz olmayan gruba göre anlamlı derecede daha yüksek saptandı $(\mathrm{p}<0.05)$. Her 2 grupta folat düzeyleri ile metastaz arasında ilişki saptanmadı ( $p>0.05)$ (Tablo 2). Metastatik mide ve kolon kanseri gruplarının folat ve B12 ortalamaları Şekil 1,2'de verilmiştir. 


\section{TARTISSMA}

Karsinogenezisin oluşabilmesi için DNA stabilizasyonunu sağlayan metilasyonun bozulması çok önemlidir. Hipermetilasyon tümör baskılayıcı genlerin fonksiyonlarını kaybetmesine sebep olarak, hipometilasyon ise kromozomal kırılma ve mutasyonların artmasına sebep olarak karsinogenezise neden olabilir. Bu nedenle azalmış folat düzeylerinde karsinogenezisde artma beklenir (6). Yu-Rong ve arkadaşları 38 mide kanserli hastanın doku folat düzeylerini normal mide biyopsileri ile karşılaştırmışlardır. Tümörlü dokunun folat düzeyleri normal dokuya göre daha düşük saptanmıştır (7). Giovanucci ve Kim yaptıkları çalışmalarda, KRK gelişiminde azalmış folat düzeyinin önemli olduğunu saptamışlardır $(8,9)$. Alonso ve arkadaşlarının yaptıkları çalışmada KRK tanısı konmuş hastalardan malign doku ve normal kolon biyopsi örnekleri alınmış ve doku folat düzeyleri karşılaştırılmıştır. Malign dokuda ölçülen folat konsantrasyonu, normal dokuya göre yüzde 50 daha düşük saptanmıştır (10). Bir başka çalışmada 15 yıl ve daha uzun süre yüksek doz folat verilen hastalarda KRK riskinin yüzde yetmişbeş azaldığı saptanmıştır (11). Benzer olarak Freudenheim ve arkadaşları yüksek doz folat alınmasının kadinlarda kolon ve rektum kanserini, erkeklerde sadece kolon kanserini azalttığını bulmuşlardır (12). Bu çalışmada kanserli grubun folat seviyeleri kontrol grubuna göre anlamlı olarak düşük saptandı $(\mathrm{p}=<0,001)$. Bu bulgu daha önceki çalışmalarla örtüşmekteydi. Fakat mide kanseri grubu ile KRK grubu arasında folat düzeyleri açısından anlamlı farklılık saptanmadı $(\mathrm{p}>0.05)$.

İnsan vücudunda vitamin B12; karaciğer, enterosit, endotel, monositler tarafindan sentezlenen transkobalamin-II (TCII) ve tükrük bezleri, mide epiteli, myeloid hücreler tarafından sentezlenen haptocorrin (HC) ile taşınmaktadır. TC-II ve HC'in vitamin B12 bağlı olmayan hallerine apo-TC-II ve apo-HC denilmektedir. Vücuttaki apo-TC-II ve apo-HC seviyelerini artıran durumlarda dolaşımdaki vitamin B12 düzeyi artmaktadır (4). Meme, kolon, pankreas ve mide kanserlerinde apo-TC-II ve/veya apo-HC'nin zaman zaman ciddi olarak yükseldiği görülmektedir (13-15). Ayrıca granülositler tümör varlığında, tümörle ilişkili uyarı ile yüksek apo-HC'ye sebep olabilirler. Ek olarak bazı tümörlerin kendileri HC üretiyor olabilir (16). Gürdal ve arkadaşlarının yaptıkları çalışmada akciğer kanserli hastalarda vitamin B12 düzeyleri kontrol grubuna göre anlamlı derecede yüksek bulunmuştur (17). Benzer olarak prostat kanserli hastalarda risk faktörlerini araştıran bir çalışmada, yükselmiş vitamin B12 seviyesi ile artmış prostat kanseri riski arasında anlamlı ilişki olduğu ve yüksek vitamin B12 seviyesinin riski üç kat artırdı ̆̆ı bulunmuştur (18). Geissbühler ve arkadaşlarının yaptıkları çalışmada da yükselmiş serum vitamin B12 düzeyinin kanserli yaşlı hastalarda mortalite için prediktör bir faktör olabileceği gösterilmiştir (19). Bu çalışmada tüm kanser grubunun vitamin B12 ortalaması, kontrol grubuna göre anlamlı olarak yüksek saptandı $(\mathrm{p}<0.05)$. Bu sonuç, aynı zamanda yukarıdaki çalışmalarla paralellik göster- mektedir. Bununla birlikte, mide kanseri grubu ile KRK grubu arasında, vitamin B12 açısından anlamlı bir farklılık saptanmadı ( $\mathrm{p}>0.05)$.

Karaciğer hastalıkları, plazma vitamin B12 seviyesinde yükselmelere sebep olabilir. Bu yükselme, kronik karaciğer inflamasyonu ve patolojilerinde, depolanmış vitamin B12'nin hepatosit yıkımı ile salınımına ve/veya hepatosit etkilenmesi ile TC-II sentez kapasitesinin azalmasına bağlıdır (20). Ayrıca karaciğeri etkileyen tümörlerde vaskülarizasyonun az olması ve/veya tümörlü hepatositlerdeki asiloglikoprotein reseptör sayısının azalmasına bağlı olarak vitamin B12 klirensinin azalmasının sonucu olarak kandaki vitamin B12 seviyesi yükselir. Tümör boyutu ile plazma vitamin B12 seviyesi arasında pozitif kolerasyon olduğu yüzlerce vakada gösterilmiştir $(21,22)$. Karaciğere metastaz yapmış meme, kolon, pankreas ve mide kanserlerine sahip hastaların yüzde kırkında yükselmiş vitamin B12 seviyesi gösterilmiştir. Hatta bazı vakalarda referans limitlerin üst sınırını 30 kat aşan değerler gözlenmiştir. Bu aşırı yüksek değerlere, hepatosit yıkımı neden olmuş olabilir (13-15). Venöz yolla hematojen yayllım erken mide karsinomlarında nadir, ilerlemiş mide karsinomlarında daha sık olup en sık karaciğer metastazı görülmektedir (23). Kolorektal kanserin en yaygın uzak metastaz yeri karaciğerdir. 1lk başvuruda hastaların yüzde yirmibeşinde karaciğerinde metastazlar vardır. Bazen hepatik metastazların yüzde sekseni primer rezeksiyondan sonraki 2 yıl içinde ortaya çıkmaktadır. Tedavi edilmeyen hepatik metastazların kötü prognozundan dolayı agresif yaklaşım gereklidir (24). Bu çalışmada, mide kanseri ve KRK grubunda karaciğere metastaz yapan ve yapmayan olguların folat ortalamaları arasında anlamlı farklılık saptanmadı ( $p>0.05$ ). Mide kanseri grubunda karaciğere metastaz yapmış ve yapmamış olgulardaki vitamin B12 düzeyleri arasında anlamlı farklılıklar bulunmadı ( $\mathrm{p}>0.05$ ). Fakat kolon kanseri grubunda metastaz saptanan olguların ortalama vitamin B12 düzeyleri, metastaz yapmayanlara göre anlamlı olarak yüksek saptandi $(\mathrm{p}<0.05)$.

Bu çalışmada mide ve kolon kanseri tanısı konulan hastaların, serum folat düzeyleri düşük, vitamin B12 düzeyleri yüksek tespit edilmiştir. Metastaz yaptığı bulunan olguların folat ortalamaları, metastaz yapmayanlarla benzer iken, metastaz yapan kolon kanserli hastaların vitamin B12 düzeyleri, metastaz yapmayanlara göre daha yüksek saptanmıştır. Yüksek vitamin B12 düzeyinin, özellikle kolon kanseri için karaciğer metastazını göstermede bir parametre olabileceği düşünüldü. Fakat karaciğere metastaz yaptığı saptanan birkaç olguda normal ve/veya düşük vitamin B12 düzeylerinin olması, metastazı göstermede vitamin B12'nin tek başına güvenli bir parametre olmadığını göstermektedir. Bu sonuçlar, çalışmaya alınan ve metastaz saptanan hasta sayısının az olmasına bağlı olabilir. Mide ve kolon kanserinde vitamin B12 düzeylerinin karaciğer metastazı ile ilişkisinin tespiti ve folat'in mide ve kolon kanserini önlemedeki etkinliğinin tespiti için daha fazla sayıda hasta ile yapılan geniş ölçekli çalışmalara ihtiyaç vardır. 


\section{KAYNAKLAR}

1. Miller SM, Mears M. Nutritional Status Assessment. In: Anderson SC, Cockayne S (eds). Clinical Chemistry Concept and Applications. New York: Mc Graw Hill; 2003:579-611.

2. Dahlin A, Guelpen B, Hultdin J, et al. Plasma vitamin B12 concentrations and risk of colorectal cancer: a nested case-referent study. Int J Cancer 2008;122:2057-61.

3. Duthie SJ, Narayanan S, Sharp L, et al. Folate DNA stability and colorectal neoplasia. Proc Nutr Soc 2004;63:571-8.

4. Ermens A, Vlasveld L, Lindemans J. Significance of elevated cobalamin (vitamin B12) levels in blood. Clin Biochem 2003;36:585-90.

5. Boisson F, FremontS, Migeon C, et al. Human haptocorrin in hepatocellular carcinoma. Cancer Detect Prev 1999;23:89-96.

6. Hubner RA, Houlston RS. Folate and colorectal cancer prevention. Br J Cancer 2009; 100:233-9.

7. Weng YR, Sun DF, Fang JY, et al. Folate levels in mocosal tissue but not methylenetetrahydrofolate reductase polymorphisms are associated with gastric carcinogenesis. World J Gastroenterol 2006;12:7591-7.

8. Giovannucci E. Epidemiological studies of folate and colorectal neoplasia. J Nutr 2002;132:2350S-5S.

9. Kim YI. Folate and carcinogenesis: evidence, mechanisms and implications. J Nutr Biochem. 1999;10:66-88.

10. Alonso E, Gonzales MP, Poo R, Varela G. Folate status and S-adenosylmethionine/ S-adenosylhomocysteine ratio in colorectal adenocarcinoma in humans. J Clin Nutr 2008:62;295-8.

11. Giovannucci E, Stampfer MJ, Colditz GA, et al. Multivitamin use, folat and colon cancer in women in the Nurses Health Study. Ann Intern Med 1998;129:517-24.

12. Freudenheim JL, Saxon G, Marshall JR, et al. Folate intake and carcinogenesis of the colon and rectum. Int J Epidemiol 1991;20:368-74.

13. Gimsing P, Hippe E. Increased concentration of transcobalamin I in a patient with metastatic carcinoma of the breast. Scand J Haematol 1978;21:243-9.
14. Carmel R. Extreme elevation of serum transcobalamin I in a patient with metastatic cancer. N Engl J Med 1975;292:282-4.

15. Carmel R, Eisenberg L. Serum vitamin B12 and transcobalamin abnormalities in patients with cancer. J Cancer 1977;40:1348-53.

16. Wakatsuki Y, Inada M, Kudo $\mathrm{H}$, et al. Immunological characterization and clinical implication of cobalamin binding protein in human gastric cancer. Cancer Res 1983;49:3122-8.

17. Gürdal E, Karadağ M, Özyardımcı N, ve ark. Cigarette smoking, serum lipids, folate and vitamin B12 in lung cancer. J Environ Pathol Toxicol Oncol 1996;15:161-7.

18. Johan H, Guelpen B, Bergh A, et al. Plasma folate, vitamin B12, and homocystein and prostate cancer risk: a prospective study. Int J Cancer 2005;113:819-24

19. Geissbühler P, Mermillod B, Rapin CH. Elevated serum vitamin B12 levels associated with CRP as a predictive factor of mortality in palliative care cancer patients; a prospective study over five years. J Pain Symptom Manage 2000;20:93-103.

20. Salles N, Hermann F, Sieber C, Rapin C. High vitamin B12 and mortality in elderly inpatients. Journal of Nutrition. 2008;12:219-21

21. Kane SP, Murray IM, Paradinas FJ, et al. Vitamin B12 binding protein as a tumor marker for HCC. Gut 1978;19:1105-9.

22. Wheeler K, Pritchard J, Luck W, Rossiter M. Transcobalamin I as a marker for fibrolamellar hepatoma. Med Ped Oncol 1986;14:227-9.

23. Karpeh MS, Kelsen DP, Tepper JE. Cancer of the stomach. DeVita VT Jr, Hellman S, Rosenberg SA (eds). Cancer principles \&pPractice of oncology. Lippincott Williams \& Wilkins, 6th ed. Philadelphia; 2001:1092126.

24. Lavery IC, López-Kostner F, Pelley RJ, Fine RM. Treatment of colon and rectal cancer. Surg Clin North Am 2000;80:535-69. 